\title{
The Vesalian School of Anatomy in
}

\section{Renaissance Padua}

JOHN MARTIN, M.D.

When we trace the steadily swelling currents of medical thought over some thirty centuries, from the shadowy beginnings in the Greek era, which we now look upon as a fascinating mixture of myth and truth, to our modern sophisticated techniques in medicine and our hundreds of richly-endowed libraries, where can we say, "This was the century, this was the year, this was the school" where one great change was made which brought us to our present refinements? What man or school was the key to the almost terrifying acceleration of knowledge in the biological sciences which has occurred within living memory?

As in most progressive movements in human endeavor, there has been one main current, one great stream, moving inexorably, receiving small and large tributaries, swelling only imperceptibly with gifts from small rivulets, but quickening speed when a major stream, draining vast new areas, suddenly floods into the main channel. Cross currents and back eddies add new riches to the onward flow. Thus we owe our great medical heritage to the accumulated gifts of hosts of nameless, unsung scholars no less than to the more familiar accomplishments of the better known, more often praised, medical giants.

Just as all present-day therapeutics are based ultimately upon a knowledge of the structure of the human body, so, from earliest times until well into the seventeenth century, the fabric of medical history depends upon anatomy for its framework. The Greek Alcmaeon dissected animals as early as the sixth century B.C., this being most likely the earliest record of such investigation, though in all probability he was not the first to do so. For the next three or four centuries the "Hippocratic School" was more interested in the treatment of disease than in anatomy as a special pursuit; yet this era did produce lasting records, both accurate and faulty, of information gained from the examination of butchered animals, wounded men, and dead human remains. 
Aristotle and his school ( $\mathrm{ca} .350$ B.C.) were interested in the broad field of biology, but they did expound anatomy, often erroneously, together with physiology, and the Aristotelian influence was felt for two millenia thereafter. When Alexander's empire collapsed in 323 B.C., the center of learning shifted from Athens to Alexandria, where two of the greatest investigators and teachers of pre-Christian times, Herophilus and Erasistratus (ca. 300-250 B.C.), studied anatomy and left records of original discoveries, particularly in neurological anatomy, their records having been later collected and forwarded into the gathering stream by Galen of Pergamum (130-200 A.D.).

Of Galen much has been written. In fact, as one reads the story of medical growth up to 1600 or even later, one grows a bit weary of Galen. Alert, peripatetic, wealthy, well educated, self-confident, obviously brilliant and gifted, Galen was interested in the total knowledge of anatomy, physiology, and therapeutics of his time. He not only assembled what he considered important from earlier times but also added much new material of his own, a mixture of anatomy and physiology, which was highly original and often surprisingly correct. Yet it was often riddled with faults and confused by a lack of respect for nomenclature. So positive were his prononuncements, so attractive and persuasive were his solutions to old problems, so didactic, so allinclusive were his prolific writings, that this "Prince of Physicians" hypnotized centuries of men well into the Renaissance, and unfortunately his errors were perpetuated by even later writers. It was only because of the force of a few fresh minds throwing their independent thought into the stream, often at personal sacrifice, that the old $\mathrm{Ga}$ lenic rules and tenets were gradually replaced by a solid working knowledge of anatomy and physiology.

In the later days of the Roman Empire and throughout the "Dark Ages" of Europe, there was little or no interest in science in any form in the Christian world. But certain authorities, such as Aristotle, Celsus, Oribasius, Paul of Aegina, and also Galen, were the forces which loosely bridged this era, and whose writings were translated into Syriac and Arabic. From these translations came the copy work of the Moslems. Dissection and pictorial representation of animal objects being forbidden by the Moslem religion, anatomy could hardly hope to develop beyond its static state during an era of Moslem supremacy in the perimeters of the Mediterranean.

The first stirrings of a renaissance, of a rising out of the murk of the Arabic influence and the bonds of Galen, came early in the fourteenth century in Italy, when it became possible for physicians legally to perform human dissections. Such dissections, usually of a body of 
an executed criminal, were held publicly and hurriedly. Means of preserving the body for a slow and careful study were lacking, and so errors abounded, but a feeling that animal dissection could no longer be substituted for human dissection was becoming established. Italy, recognized as the cradle of the Renaissance for the humanities and the arts, also produced the first teaching anatomist in the legendary Mondino de' Luzzi of Bologna, whose book, the Anathomia (1316), was a manual and text for human dissection. It remained a standard for over two hundred years; yet so tradition-bound was the advanced scholar Mondino that his reasoning was entirely scholastic and given over to verifying the old Arabic and Galenic formulations. He might be holding a human uterus in his hand, yet he saw the seven-celled structure of Galen. He had before him the human heart, and yet he could verify Avicenna's claim to a third ventricle. Progress was slow. Except for a few schools in Italy, as at Bologna, Padua and Venice, and gradually beyond the Alps in Montpellier and Paris, few scholars interested strictly in medicine appeared on the scene, and those who did, even in the great centers of learning, seemed mesmerized into restating the old concepts, those comfortable old rules which did away with the need for new digging and probing. In fact, throughout the fifteenth, sixteenth and seventeenth centuries, reputations suffered when Galen was questioned or demonstrated to be wrong.

In the decades following the invention of movable type, art work began to find an outlet in printed books, as is evidenced in our rich legacies from Raphael, Leonardo da Vinci, Michelangelo, Dürer, Mantegna, Verrochio, and others. In 1491 there appeared in Venice perhaps the first printed work devoted exclusively to medicine, Ketham's Fasciculus Medicinae. This was actually the collected works of various authors, containing also the text of Mondino's Anathomia, and it was illustrated with the first anatomical woodcuts. If not entirely accurate, they were at least an indication that an interest in beauty and artistic presentation was afoot in things medical. From the Fasciculus on, beginning particularly with Berengarius, anatomical illustration flourished increasingly, with emphasis on accuracy as well as beauty.

Of the several notable pre-Vesalian anatomists, none of Padua, one who early made a definite and courageous break from Galen was Berengario da Carpi (Berengarius, 1470-1550), professor of surgery at Bologna. His textbooks were the first truly anatomical works that were illustrated. Though most of the figures are crude compared to those in works soon to follow, they were the result of actual human 
dissection and independent critical examination. For instance, Berengarius had the temerity to deny the presence of a rete mirabile at the base of the brain, contrary to both Galen and Mondino, simply because he consistently did not find such a structure on dissection. His Latin was grammatically poor and the books were small and poorly made, but his Isogogae Breves (Bologna, 1522) was a first bold and independent statement. Others, such as Paracelsus (1493-1541), Charles Estienne (1503-1564), Johannes Dryander of Marburg (15001560), and Canano of Ferrara (1515-1579), produced original and improved anatomies shaped by the growing interest in the use of artful illustration; but none of these, nor contemporaries equally scholarly, was entirely free of the old Galenic-Arabic shackles.

The humanistic movement (approximately 1450-1550) saw improvement in Latin as a scholarly language, the use of new translations from the original Greek and Latin texts free of errors from several centuries of copy work at the hands of Moslem scribes, and a progressive escape from the slavish perpetuation of Galenic rules. The story of such men as Benedetti (1455-1525), whose efforts marked the beginning of the rise of Padua as the center of anatomical study during the early Italian Renaissance; Montanus (1498-1551), another Paduan; the Englishman, Thomas Linacre (1460-1524); Johannes Günther of Andernach (1487-1574); Michael Servetus (1511-1553); Sylvius of Paris (Jacques Dubois, 1478-1555); and Vesalius himself (1514-1564) is a record of humanistic effort in the purest sense of the word. Their wide dispersion throughout Italy, Germany, France, and England indicates the force with which fresh energies were pushing out into new regions of intellectual activity. It was a time of ferment in awakening science; and in the field of anatomy, Padua was the magnet which drew scholars from all the other centers. Renaissance Padua, through the days of Spigelius, was to rise to heights it had never known and was never again to know.

Three hundred years of slow work had developed emerging new anatomical techniques, and they were now to be taken up "by one who was prepared as if by fate to command them all and to use them single-handed for the final shattering of blind tradition." 1 Historians recognize Andreas Vesalius (1514-1564) as the cleavage point. Born to a wealthy Brussels family, Vesalius received his early education in Louvain. In 1533 he went to Paris to study under Jacobus Sylvius and Johannes Günther, both staunch Galenists and both leading teachers and intellectuals. It is to the credit of neither Vesalius nor Sylvius that these two quarreled over Galen; but young Vesalius, naturally

1 George W. Comer, Anatomy, Clio Medica, vol. 3 (New York, 1930), p. 20. 
questioning and skeptical, did not hesitate to point out what visual inspection proved obvious. With Günther he had good rapport, and he helped revise Günther's great Institutionum Anatomicarum Libri Quatuor (Basel, 1536; revised, Venice, 1538). In the same year he published six large sheets of anatomical figures, the Tabulae Anatomicae Sex (Venice, 1538), sometimes called "fugitive sheets," which served to illustrate, in Galenic fashion for the most part, the Anatomical Institutions of Günther. These two early works of Vesalius were important in his career because they brought him into close association with Günther, and they were almost a "practice preparation" for his one great work yet to come. Even so, Vesalius was still unable completely to dissociate his thinking from Galen, in spite of his increasing experience in human dissection. The Tabulae Sex show continuing errors, such as a seven-part sternum and a five-lobed liver.

Early in the fifteenth century Padua had been incorporated into the Republic of Venice, where Vesalius was to find not only a freer spirit of thought but also a more liberal attitude toward human dissection. Though procurement of bodies was never an easy task, less grave robbing was necessary, and dissections were carefully done before large and admiring audiences of students and visiting scholars. Vesalius, already with his great opus the Fabrica in mind, had vowed to abolish the "execrable rites" of dissection done in sloppy fashion by barber-surgeons which he had witnessed in Paris. He settled in Padua in 1537, and with fiery ardor dissected many human bodies. studied bones continuously, read and re-read Galen with an ever more critical eye, and for five years utterly devoted his entire time and energy to anatomy.

In 1541 Vesalius was asked by Günther to assist in editing the great complete Latin edition of Galen, the "first Giunta" edition, the work having been translated from the Greek by Günther. Vesalius edited the sections on "Dissection of the Nerves," "Dissection of the Vessels," and "Manual of Dissection." Not only did this give Vesalius good experience with carefully-written Latin, for the great humanist Günther was an accomplished scholar in languages, but it also gave him opportunity for close comparison of Galen's descriptions with his own increasingly critical dissections. He found many discrepancies. His doubts flowered into open statements of disagreement, and his iconoclastic zeal to prove it all in one great work was fired to increasing heat. From the time of his appointment as professor of anatomy at Padua in 1537 until the appearance of De Humani Corporis Fabrica Libri Septem (Basel, 1543), Vesalius, artist, naturalist, devout Catholic, did not deviate from his single aim. He bound himsclf to present 
the anatomy of man as a "great living design," a complete exposition of this great plan of God Himself.

The Fabrica was dedicated to Emperor Charles V on August 1, 1542, and the colophon bears the date of June, 1543. It was, and is, a magnificent and epoch-making creation. Such an exhaustive text, such a profusion and richness of illustration coupling accuracy with art, had never before seen light in the world. The Fabrica does contain many errors and it is not entirely free from the influence of Galen, as attested by the many respectful references to that old Greek; but this sumptuous book is new and orderly in an unprecedented way for an anatomical text and atlas. It was designed by $\mathrm{Ve}$ salius himself and printed under his direction by his friend Oporinus of Basel.

Vesalius was well aware of the value of good illustrations, and he, together with Calcar, a pupil of Titian, prepared the drawings. ${ }^{2}$ The drawings were cut on blocks of pear wood prepared with linseed oil and cut cross-grain by a now-unknown block cutter, and then transported by mule-back probably over the St. Gotthard Pass from Venice to Basel. Compared with the flat, conventional, strictly utilitarian illustrations in modern texts of anatomy, the Fabrica's three-dimensional figures, set before artistic backgrounds and suggesting action, have by general consensus never yet been equalled. How many books have been written about these famous illustrations! How often they have been reproduced as the example of an astounding twenty-eight year old mind ${ }^{3}$ They continue to set a standard of excellence.

The Fabrica of 1543 is a large folio of six hundred sixty-three pages with seventy-three text plates, a portrait of Vesalius dissecting the arm, an intricate and detailed title page, and numerous decorative capital letters. ${ }^{4}$ Both the portrait and the title page have been the subject of much conjecture and discussion among historians, and for both these plates new blocks were cut for the 1555 edition. ${ }^{5}$ After a long introductory dedication and preface, the reader finds the seven books which make up the text. The first book is concerned with the

2 There may also have been other artists involved in the project, for the matter of the artists who produced the illustrations has long been a source of argument and conjecture.

3 In Book I, Chapter VI of the Fabrica, Vesalius wrote: "As I write [i.e., in 1540], my thirty-second tooth is erupting in my twenty-sixth year."

4 Many of the illustrated capital letters show busy, mischievous putti robbing graves, operating on animals, dissecting cadavers, and playing "anatomical and physiological" pranks on one another.

5 The Fabrica was reissued in 1555 in even more lavish form, with revisions in both text and figures, and was again printed by Oporinus. According to Singer, there were at least twenty-five editions (unauthorized) up to 1782 , but none of 
bones and joints. Vesalius' descriptions of the bones are far above anything else that had so far appeared, and they correct some of the errors of the Tabulae Sex; yet even so, the book shows much Galenic influence. But for the first time human bones looked living and functional, not dry and lifeless. The plates of the standing articulated skeleton even show emotion, so dramatically are they postured.

The next book of the Fabrica deals with the muscles. To be fully appreciated, these famous plates must be compared to anatomical illustrations which preceded Vesalius, such as those of Berengarius or Eustachius. Here is living anatomy; the figures appear to be in motion in their expressive poses. It was Harvey Cushing who pointed out that the scenic backgrounds, if placed in a circular diorama, picture the Paduan countryside of the time.

The third book is devoted to the vascular system, and Singer ${ }^{6}$ states that this is perhaps the least satisfactory book of the Fabrica. The illustrations and textual descriptions contain some errors but they are superior to any previous descriptions, and the artist has avoided the stiff diagrammatic representation which had been standard. There is a fresh and accurate presentation of the course of the arteries and veins through the heart and lungs.

The nervous system is the subject of the fourth book. While the illustrations are original and artfully drawn, they and the text contain many errors. The surface of the brain is well represented, but the pons is not shown. Only seven pairs of cranial nerves are described, and Vesalius failed to distinguish the motor and sensory roots of the spinal nerves. He did, however, point out the difference between the course of the left and right recurrent laryngeal nerves. Except for the peripheral nerves, the soft tissue of the nervous system would not lend itself to careful, detailed examination if the body had lain unrefrigerated or unembalmed for a few days, and this may in part explain some of the errors. Since practically nothing was known of the physiology of the nervous system, no hints were to be had from that direction in determining some of the finer points of neuroanatomy.

The fifth book is concerned with the abdominal viscera; and considering the fact that this region contains structures and relationships of such detail that their pictorial representation is still a problem, one

them by any means approached the beauty and opulence of the original two. Even before his death and for decades later, Vesalius was plagiarized shamelessly by anatomists, a fact which he repeatedly denounced. But all that actually was tribute to him.

6 Charles Singer, A Short History of Anatomy and Physiology from the Greeks to Harvey, 2nd ed. (New York, 1957), p. 134. 
must applaud the success of these early wood blocks. Again, errors abound. The appendix is pictured but not mentioned in the text. There is very little information concerning the embryo. While the genitourinary organs of the male are fairly well described and pictured, those of the female are poorly done compared with so much else in the Fabrica which is first rate.

The sixth book describes the thoracic viscera, and while the 1543 edition of the Fabrica generally follows the anatomy and physiology of Galen, most of these errors were corrected in the 1555 edition. The heart receives better treatment than the lungs, the right lung being shown with only two lobes. A very important statement in the description of the heart is Vesalius' assertion that on repeated probing and searching he could not find any passageway through the cardiac septum which would allow blood to pass directly from the right into the left ventricle.

The seventh book has to do with the brain, and the figures are entirely original in concept. With the calvarium removed we see the brain sectioned serially in horizontal fashion, in situ, clearly showing the ventricular system, the basilar ganglia, the mid-brain, the pineal gland (to which Vesalius, as many before and after him, gave great functional importance), and structures on the floor of the skull.

There is a terminal chapter of the Fabrica which describes some of the methods of physiological experimentation which Vesalius employed, including vivisection. He showed that the spleen could be removed without loss of life; that the action of the brain, whatever it was, was transmitted through the spinal cord and nerves to the somatic areas; and that the recurrent laryngeal nerves controlled the voice. Vesalius used many anatomical terms borrowed from Celsus, Galen, Aristotle, Günther, and others, but in general he had respect for an orderly, consistent nomenclature, and he originated some terms of his own. He gave us, among many others, atlas, choanae, corpus callosum, incus, and mitral (valve). ${ }^{7}$

Vesalius' great contribution to science was complete with the Fabrica of 1543 . He was not yet twenty-nine years old. His break with Galenism was a marvel of transformation for his era, and it is the

7 Besides the Fabrica, the work with Günther in 1538 and 1541 on the Galen translations, and the Tabulae Anatomica Sex already mentioned, several other important works of Vesalius are known, if not all still extant. Issued at Basel in 1543 almost simultaneously with the Fabrica was the Epitome, a brief student"s compendium with nine illustrations and text. This book is now excessively rare. Perhaps the final episode of Vesalius' studies at Louvain was the publication of Paraphrasis in nonum librum Rhazae medici arabis clariss. (1536), his thesis for the degree of Bachelor of Medicine. Other publications which the student of Vesalius cherishes are The Venesection Letter (Basel, 1539), The Letter on the China 
key to his fame and to the rapid expansion of anatomical progression from that time on. Important as was the new and accurate anatomical information in the Fabrica, the scientific principles and pedagogical methods of Vesalius were even more important because they were fundamentally true, and they were to remain unchallenged. The bonds of tradition had been broken and the great new era of independent observation and experimentation had been opened.

As if he himself realized this, Vesalius gave up his teaching and anatomical studies in 1543 and became court physician and military surgeon to Emperor Charles $\mathrm{V}$ and later to the Emperor's son, Phillip II of Spain. Of his personal life we know little, other than that he was married, had one daughter, and apparently was in sound financial condition all his life. It is possible that in 1562 on the death of his successor at Padua, Gabriele Fallopio, Vesalius wished to return to his old work in the anatomical theater at the University of Padua, but in any event Phillip would not at that time allow him to leave Spain. He made a pilgrimage to Jerusalem in 1564; and about that voyage, his death, and burial there are many accounts and legends, most of them no doubt apocryphal. We do know that he was either shipwrecked off the coast of the island of Zante or put ashore there because of illness, and that he died there and for many years lay in an unmarked grave. To this somber note may be added another concerning the wood blocks of the Fabrica, that great monument to man's intellect which had appeared the same year as another famous scientific landmark, On the Revolution of the Celestial Spheres (1543), by Nicholas Copernicus. Long carefully preserved intact, the wood blocks of the Fabrica were destroyed by the Allied bombing of Munich in World War II. Vivitur ingenio, caetera mortis erunt (Genius lives on, all else is mortal). ${ }^{8}$

Together with Vesalius, the next five men in charge of anatomical teaching at Padua comprise the "Vesalian School of Padua." The im-

Root (Basel, 1546), and his last work, an important one, the Anatomicarum Gabrielis Fallopii Observationum Examen (Venice, 1564). Vesalius left a considerable volume of both medical and non-medical correspondence which is revealing as to the personal qualities of the man and his remarkable capabilities as a practising clinician. One of the most interesting and charming of these is his consilia, dated Madrid, 1562, to the physician Gian Filippo Ingrassia of Naples (Pro Magni, et illustr. Terraenovae Ducis Fistula, ex levi axilla in thoracis concavum pervia, etc.) in which he clearly describes his remarkably modern surgical treatment of empyema.

8 "In the original version of the above plate [Plate 22, side view of the skeleton posed Hamlet-wise with a skull] the motto Vivitur ingenio, caetera mortis erunt"Cenius lives on, all else is mortal'-was inserted on the side of the tomb." J. B. de C. Saunders and C. D. O'Malley, The Illustrations from the Works of Andreas Vesaltus of Brussels (Cleveland, 1950), p. 86. 
mediate successor to Vesalius was Realdus Columbus (1516-1559), pupil and assistant to Vesalius, whose only written anatomical work, De Re Anatomica (Venice, 1559), appeared posthumously. This book shows some residual Galenic reasoning, but over all it is a marked advance in anatomical thinking, particularly in its treatment of regional anatomy (the mediastinum, pleural and peritoneal cavities, the organs of speech). The words bregma and pelvis were first used by Columbus in their modern context. The book suffers from having no illustrations. Some of Columbus' statements show him to have been a bitter man, and he did not hesitate to bring a charge of fraud against his old master Vesalius.

Columbus is important to medical history because he was the first, not counting Servetus, ${ }^{9}$ to make a clear statement concerning the circulation of the blood as it would come to be understood. Though Vesalius and others had made a crack in the old teachings on the circulation and the structure of the heart, it was Columbus who first demonstrated the lesser circulation experimentally, sixty-nine years before the matter was to be clearly and finally stated by William Harvey, who had also been trained at Padua. Indeed, not all credit for the discovery of the true circulation should go to Harvey, for earlier Leonardo da Vinci, Berengarius, and Vesalius had had some vision of the truth.

Columbus dealt directly with the vexing problem of the opening in the septum of the heart through which blood had been supposed to pass from right to left. In criticizing the Galenists he stated, "But they follow a false path, because the blood goes through the vena arteriosa [pulmonary artery] to the lungs and is there attenuated; then, mixed with air, it goes through the arteria venosa [pulmonary vein] to the left heart, just as everyone may observe but which no one has obscrved up to this day and no one has stated in his writings." Columbus was in error in much of his reasoning about the circulation. He still supported the persistent old idea that the veins car-

9 Michael Servetus (Michael Villanovanus, 1511-1553), more militant theologian than scientist, was not a Paduan and not attached to any one school. He had independently in his Christianismi Restitutio (Vienna, 1552) made what is probably the first definite statement that there are no perforations in the cardiac septum, and he described the lesser or pulmonary circulation much as did Columbus. It seems certain that neither knew of the other's work going on simultaneously. Servetus' book, published in one edition of only one thousand copies, appeared earlier than the $D e$ Re Anatomica, but buried in a theological treatise, the statement received little notice. Both book and author were marked for tragic destruction. Because of his attack on the Trinity, Servetus was accused of heresy by the Calvinists, and together with two copies of his book he was burned at the stake in Geneva in 1553. Only three copies of the book are now known to exist. 
ried the nutritive blood through the general circulation, and that the liver was the source of the blood and the "central organ" of circulation. However, Columbus, with Servetus, must be credited with making the first definite departure from the Galenic physiology of circulation. Unfortunately, the man did not leave much written work behind, he seems not to appeal to medical historians, and he probably is not given sufficient credit for his rightful place in the development of medical science. ${ }^{10}$

Columbus was head of the department of anatomy at Padua for about two years. He was succeeded by Gabriele Fallopio (Fallopius, 1523-1562), an Italian who had studied at Ferrara, Pisa, and Padua. He was a brilliant man, quiet of nature, apparently in chronically poor health, never financially comfortable, but an independent thinker and a bold scholar. His denials of the old Galenic concepts were even more positive than those of Vesalius. His main work, the modest little Observationes Anatomicae (Venice, 1561), was not to be compared with the elaborate Fabrica. It was a much shorter text than the Fabrica, was printed on poor-quality paper at his own expense, in small octavo, and without illustrations. But Fallopius' discoveries were many, and he corrected Vesalius' description of the cerebral arteries. In fact, his variance on several points of anatomy from "the master" was what prompted Vesalius to issue his last work, the Anatomicarum Gabrielis Fallopii Observationum Examen (1564). Many anatomical structures were named by Fallopius-the Fallopian tubes, the chorda tympani, the hard and soft palate, the placenta and vagina -and he gave the first accurate description of the clitoris and the penile arteries. His account of the cerebral nerves and the ocular muscles is far superior to that of Vesalius, his teacher and idol. His carly death, probably from tuberculosis, cut short what promised to be a large output of solid work, but his strong influence continued in at

10 Another important contemporary of Columbus was Andrea Cesalpino (15191603), scientist and philosopher, and professor of medicine at Pisa and Rome. $\mathrm{He}$ is mentioned here because his work was an important contribution to the growing interest in the anatomy and physiology of the heart and circulation. $\mathrm{He}$ it was who flatly denied Galen's theory that there were different "vital principles," "humours," for the various bodily functions. He believed in one principle, the "anima," which he identified as blood and as a total body nutrient. Also, he described the circulation with the heart, not the liver, as the central driving force. He pointed out that blood from the right side of the heart, entering the lungs, passed most likely by anastomosis to vessels leading to the left side of the heart, and that, contrary to Galen, the blood did not have direct contact with the air, but rather the blood was "cooled" and renewed with life-force because the anastomosing vessels were surrounded by air. These were the telling blows which were sounding the death knell of Galenism. 
least two of his pupils, Fabricius and Coiter.11 It has been said that Fallopius was a genius, while Vesalius was a scientist.

Upon the death of Fallopius in 1562, the chair of anatomy at Padua was filled by a pupil, Gerolamo Fabrizio d'Acquapendente (Fabricius, 1533-1619). He occupied the chair for many years, during which time he demonstrated his remarkable skill as a teacher of anatomy, and it is believed that through him his pupil, William Harvey, received his inspiration to develop the experimental, inductive method in the study of the circulation. It is obvious that Harvey drew heavily upon the teachings and writings of Fabricius in his treatment of the veins in De Motu Cordis (Frankfort, 1628), and in Exercitationes de Generatione Animalium (London, 1651). Relieved in 1604 of his duties as teacher, Fabricius produced a large amount of original work with many new discoveries in human anatomy, comparative anatomy, embryology, and the newly developing field of physiology. His works contain some of the finest anatomical illustrations, all copper engravings, to be found in any atlas. His De Venarum Ostiolis (Padua, 1603 ) is perhaps his best-known work, and in it are illustrated for the first time the valves of the veins along with a good description of their form and arrangement. Such valves had been seen before by Vesalius, Eustachius and others, and while Fabricius did not understand the function of the valves, considering them to have a delaying action on the flow of the blood, nevertheless he is given credit as the "discoverer" of the valves.

In his De Formato Foetu (Venice, 1600) and the posthumouslyissued De Formatione Ovi et Pulli (Padua, 1621) Fabricius gave great new dimensions to the understanding of fetal development and to the stages of embryonic change in a long series of animals: man,

11 A Hollander, Volcher Coiter (1534-1576) studied at Bologna, Rome and Montpellier, and at Padua under Fallopius. He was a brilliant, methodical original in his field-comparative anatomy. His works were not many, but they were concise, accurate, and the first in that field of investigation. He examined eggs in various stages of incubation, and in a great variety of animals he studied the various embryonic stages, showing particular interest in the skeletal and circulatory systems. He has justly been called "the father of embryology." He noted the difference in the lungs of amphibians and mammals, examined the poison apparatus of reptiles, described the mature anatomy of a great many animals and birds, and attempted an anatomical classification of mammals. His remarkable account of the skeleton in a large number of animals, illustrated with figures drawn by himself in his Diversorum Animalium Sceletorum Explicationes (Nuremherg, 1575), would compare favorably with any modern gross anatomy text. His publications were few, and while he might be called a "lesser Paduan," he was a gifted, productive, and loyal one. He advised the anatomists of his day to study no anatomy save that of Galen, the Fabrica, the Observationes Anatomicae of Fallopius, and the works of the Roman Eustachius. Scanning the available literature of his day, we can realize how right Coiter was in this advice. 
rabbit, guinea pig, mouse, dog, cat, sheep, pig, horse, ox, goat, deer, dogfish and viper. His descriptions of the pregnant uterus, placenta, membranes and vessels are lucid and highly accurate, and he was aware of the intricate structural changes in the vascular system at birth. Fabricius may be remembered as the first of the great anatomists at Padua who, using ingenious new methods of experimentation in comparative anatomy, turned his attention from the strictly anatomical viewpoint to the question of function of anatomical structures -to physiology. During his time at Padua the still-completely-preserved anatomical theater was constructed-small, cramped, with steeply-ranked benches. Modern medical students who complain of uncomfortable seats in twentieth-century lecture rooms should visit Padua, and take comfort!

Succeeding Fabricius was his pupil Giulio Casserio of Piacenza (Casserius, 1552-1616). Casserius' name immediately summons to mind his magnificent plates of copper engravings, done with the utmost of meticulous craftsmanship and accuracy. Casserius was particularly productive in the anatomy of the special sense organs and the laryngeal apparatus, and like his predecessor he used many animals to study these particular structures in the comparative manner. In his book on the ear, heavily illustrated, he depicts his studies on that organ in adult man, child, new-born and fetus, in ape, ox, horse, dog, rabbit, sheep, goose, pig, mouse, turkey and pike, and these detailed descriptions are remarkable for one who could not have had very effective lenses with which to work.

Casserius' De Vocis Auditusque Organis Historia Anatomica (Ferrara, 1600-1601) was by far the most accurate description to date of the laryngeal structures. But our greatest heritage from this remarkable anatomist is his Tabulae Anatomicae LXXIIX, a set of copper engravings of highest artistic and antomical quality, produced at his own expense by artists and engravers whom, it is said, he quartered in his own house in order personally to oversee the details of their work. His proposed book, Theatrum Anatomicum, was never issued in his lifetime, but the plates were used later to illustrate the works of his successor, Spigelius. For the lover of fine illustration, the wood blocks of Vesalius' Fabrica and the copper plates of Casserius will be appreciated as the very apogee of anatomical illustration. According to Choulant, ${ }^{12}$ Casserius began work on his great anatomy about 1600 , and was still working on it when he died sixteen years later. Casserius himself believed rightfully that his illustrations were indeed

12 Ludwig Choulant, History and Bibliography of Anatomic Illustration, trans. Mortimer Frank, rev. ed. (New York, 1945), p. 224. 
exceptional, saying, "As regards the fabric of the human body, I will make public, pictures finished and complete in every part, which will, I venture to say, excel in nicety, clearness, and finally in workmanship and pains all that have hitherto been published." It was not an idle boast.

Spigelius, the last man in the great Vesalian line at Padua, was the pupil and successor of Casserius. Like Vesalius, he was born in Brussels and received his early education at Louvain. Adriaan van den Spieghel (Spigelius, 1578-1625) spent nine intense years in the chair of anatomy at Padua, during which time he produced several anatomical works, all published posthumously. He was an active surgeon as well. His greatest work was the De Humani Corporis Fabrica Libri Decem (Venice, 1627), containing in all ninety-seven magnificent plates, including those of Casserius. Spigelius is remembered in the anatomical term "Spigelian Lobe" (caudate lobe) of the liver. $\mathrm{He}$ added many anatomical refinements in his De Humani Corporis Fabrica, and with the excellent illustrations at his disposal gave the first adequate description of the spinal muscles. He contributed greatly to an orderly and accurate anatomical nomenclature, especially in so far as the muscles are concerned.

In his will Spigelius had asked a German physician friend, Daniel Rindfleisch (Bucretius) to publish his Fabrica, which had been prepared without any illustrations. Bucretius received from Casserius' heirs the seventy-eight plates which Casserius had prepared for his own proposed Theatrum Anatomicum. One of them was damaged or lost, and to the seventy-seven Bucretius added twenty more, drawn and engraved by the same artists who had prepared the original seventy-eight for Casserius. The ninety-seven plates were published by Bucretius under the title Julii Casserii Placentini Tabulae Anatomicae LXXIIX, omnes novae nec antehas visae: Dan. Bucretius XX quae deerant supplevit et omnium explicationes addidit (Venice, 1627). The plates were also published in the first edition of Spigelius' work, Adriani Spigelii De Humani Corporis Fabrica Libri Decem (Venice, 1627). Most accessible of the works of Spigelius and Casserius for the modern student is Spigelius' Opera, Quae Extant Omnia (Amsterdam, 1645). This remarkable book contains the twenty plates prepared by Bucretius, the seventy-seven plates obtained from Casserius' heirs, and nine plates from Casserius' De Formato Foetu (Padua, 1626), the text of which is by Spigelius, plus one plate of the hymen, making one hundred and seven in all. Anatomical illustration attained new dimensions with both the opening and closing of the Vesalian line at Padua. 
With the death of Spigelius a new era came to Padua:

With Spigelius what we may call the "heroic age" of anatomy at Padua comes to an end. What were the reasons for its passing? They appear to us to be two. On the one hand Spigelius worked exclusively on human anatomy. He abandoned the great comparative tradition that had distinguished the Paduan school from Vesalius to Casserius. His observations became more exact and refined, they gained in practical value for the surgeon, but they lost scientific interest. On the other hand, with the work of certain contemporary investigators-Sanctorius, Van Helmont, Harvey-physiology, rather than anatomy, began to attract the best minds. The new physiological era had opened, and it was some time before Padua attracted a physiologist of front rank. The star of Bologna rose again, and it was at Bologna, not at Padua, that Borelli (1608-1679) and Malpighi (1628-1694) worked in the next generation. 13

Thus, the great main stream at Padua had run its course. Other streams, too, had been flowing, but none so grand and sweeping and productive as the stream of Vesalius at Padua. In an age of political turmoil, religious wars, and abject social conditions in Europe, it is a great and lasting tribute to a relatively few men who held true to their principles and triumphed over what must have been terrible obstacles, that they should have been able to prepare a secure foundation for the future expansion of medical science. To read their texts is revealing to us who think that most medical knowledge is .recent. To behold their illustrations and realize the beauty and truth in this excellent art is humbling to us who have thought modern illustration to be a special thing. And to hold one of their precious volumes in one's own hand is a genuine privilege. To do so is to close a span of four centuries and make possible direct touch with those medical immortals. ${ }^{14}$

13 Singer, A Short History of Anatomy and Physiology, pp. 163, 166.

14 The interested reader may see in the rare medical book collection at The University of lowa books relevant to this article by the following authors: Hippocrates, Celsus, Aristotle, Oribasius, Rhazes, Paul of Aegina, Avicenna, Galen, Leonardo da Vinci, Ketham, Mondino, Berengarius, Paracelsus, Estienne, Eustachius, Dryander, Günther, Sylvius, Montanus, Vesalius, Columbus, Fallopius, Fabricius, Casserius, Spigelius, Valverdi, Harvey, Malpighi, and others. 


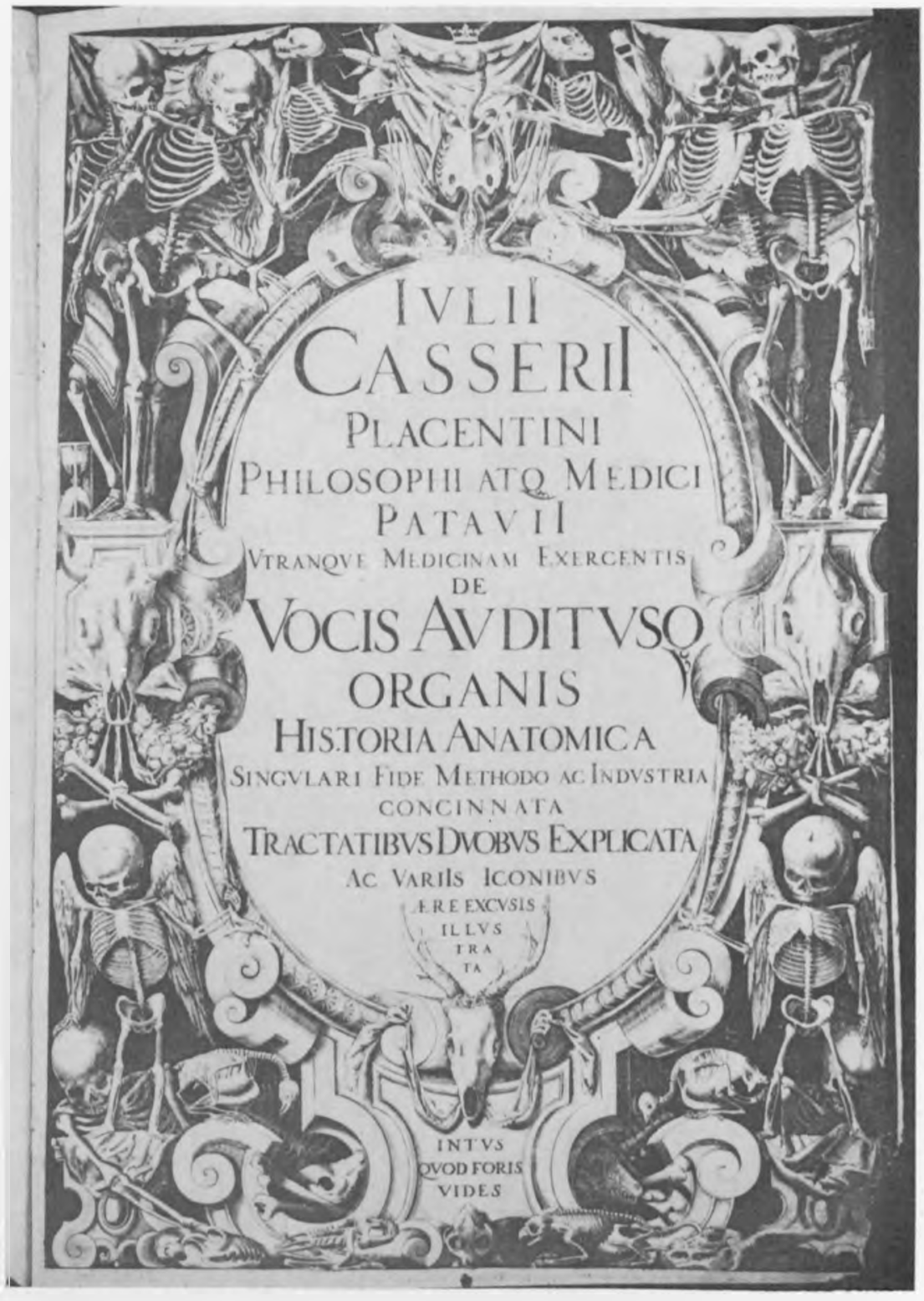

Title page of the first edition of one of the most beautifully illustrated anatonical atlases ever made, De Vocis Auditustue Organis II istoria Anatomica by Julius Casserius, published at Ferrara in the years $16(0)-1(301$. From the 1)r. John Martin copy. 


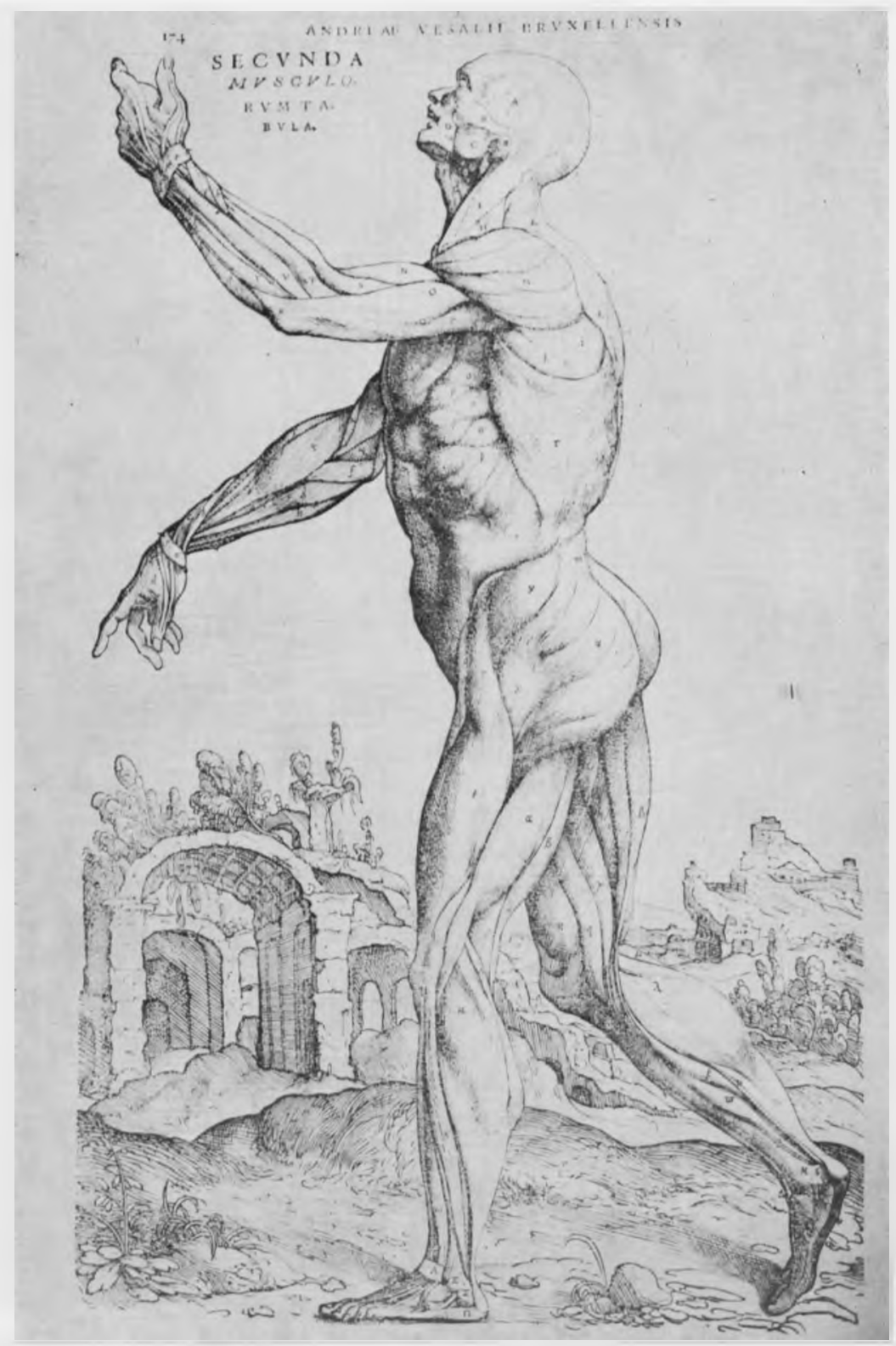

A woodblock illustration, considerably reduced, from Vesalius' De Humani Corporis Fabrica (1543), showing the second "muscle man." These early woodcuts combine art with anatomical accuracy. From the Dr. John Martin copy. 


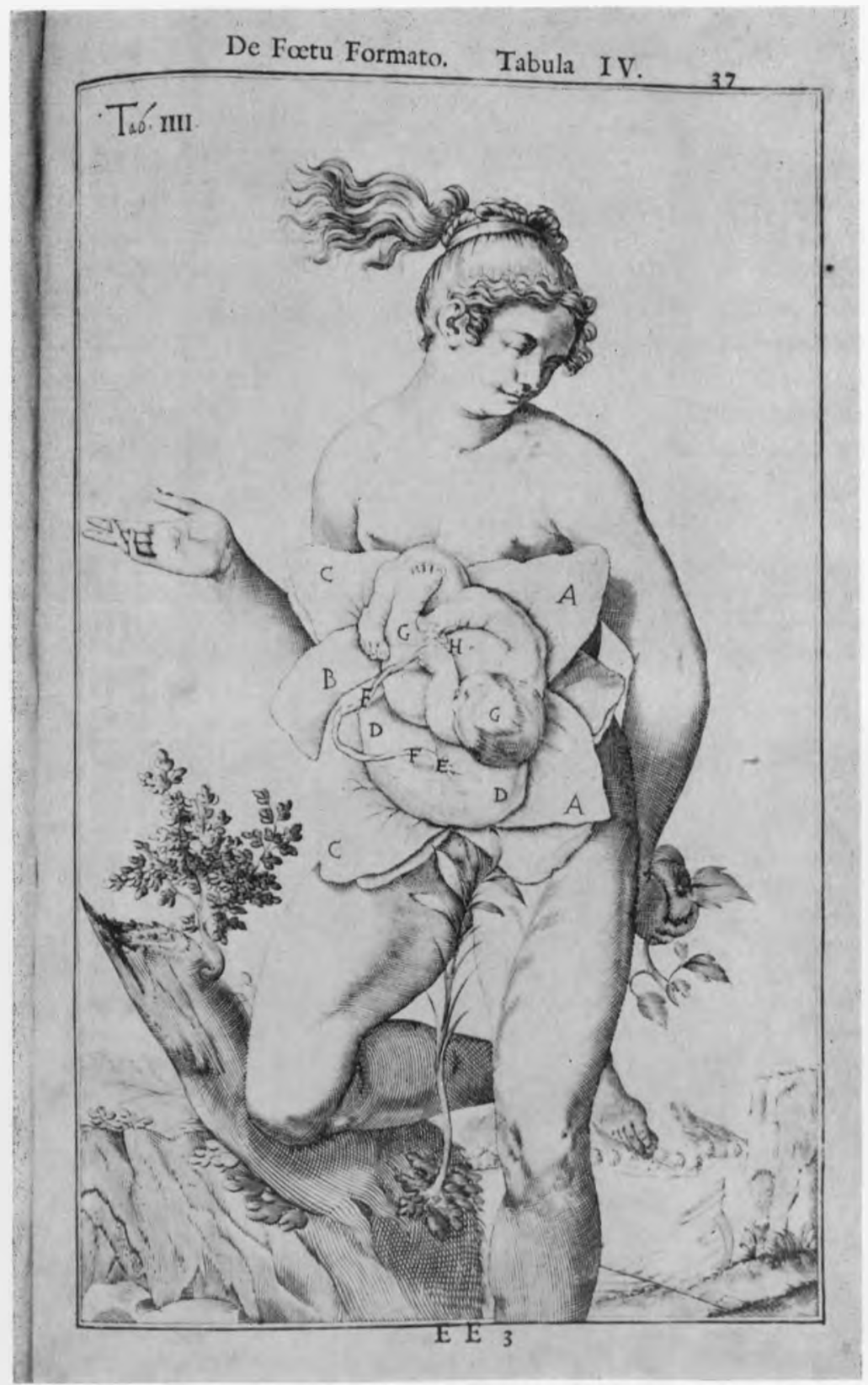

Tabula IV from De Foetu Formato (1626) by Spigelius. This figure, which measures approximately $161 / 4^{\prime \prime} \times 101 / 2^{\prime \prime}$ on the original page, is one of the seventy-eight fine copperplates prepared several years earlier by Casserius, all having been drawn with accuracy, delicacy, and remarkable clarity. From the Dr. John Martin copy. 